\section{Lovorka Magaš Bilandžić}

Filozofski fakultet Sveučilišta u Zagrebu, Odsjek za povijest umjetnosti

Izvorni znanstveni rad / Original scientific paper UDK / UDC: 766:338(497.5 Zagreb)"1922/1940" 18. 6. 2014.

\title{
Plakati Zagrebačkog zbora u međuratnom razdoblju (1922.-1940.): prilog povijesti hrvatskoga grafičkog dizajna
}

Ključne riječi: grafički dizajn, plakat, međuratno razdoblje, Zagrebački zbor, Kornel Becić, Malvine Egersdorfer, Marcel Fišer, Zvonimir Lenard

Keywords: graphic design, poster, interwar period, Zagreb Fair (Zagrebački zbor), Kornel Becić, Malvine Egersdorfer, Marcel Fišer, Zvonimir Lenard

U radu se na osnovi arhivske i periodične građe razmatra uloga Zagrebačkog zbora u promoviranju grafičkog dizajna i reklame, donosi tipologija zborskih plakata i interpretira doprinos autorskih osobnosti koje dosad nisu bile identificirane u povijesti hrvatskoga grafičkog dizajna. Korpus poznatih plakata nadopunjuje se dosad neobjavljenim rješenjima koja se promatraju kao reprezentativni primjeri vizualne kulture svoga vremena.

Zagrebački zbor (ZZ) imao je istaknutu ulogu u povijesti vizualnih komunikacija u Kraljevini SHS/Jugoslaviiji u razdoblju između dva svjetska rata te je svojim djelovanjem na različitim razinama pridonio popularizaciji i afirmaciji novih medija plakata, fotografije i reklame. Uprava Zbora posvećivala je značajnu pozornost propagandnoj djelatnosti te bila važan naručitelj plakata i (su)organizator velikih međunarodnih izložaba koje su posjetiteljima pružile uvid u razvoj grafičkog dizajna i fotografije - od Izložbe plakata (1926.) i Film und Foto (1930.) do izložaba štampe (1930.) i reklame (1934.).

Iako je dio plakata Zagrebačkog zbora bio prezentiran na tematskim i sinteznim izložbama, ${ }^{1}$ te uključen u publikacije posvećene povijesti grafičkog dizajna u Hrvatskoj, ${ }^{2} \mathrm{o}$ propagandnoj djelatnosti i plakatima Zbora objavljene su tek rijetke studije. ${ }^{3} \mathrm{U}$ članku se na osnovi arhivske i periodične građe donosi niz saznanja o reklamnoj djelatnosti Zbora, procesu narudžbe plakata i ulozi u afirmiranju grafičkog dizajna, identificiraju se autori neatribuiranih rješenja te analizira doprinos zaboravljenih grafičkih dizajnera oblikovanju vizualnog identiteta sajma. Pri tome se korpus poznatih zborskih plakata nadopunjuje dosad neobjavljenim rješenjima koja su pridonijela vidljivosti manifestacije $u$ domaćim i međunarodnim okvirima tijekom 1920-ih i 1930-ih.

Zagrebački zbor u međuratnom razdoblju $\mathrm{i}$ njegova uloga u promoviranju grafičkog dizajna i reklame

Društvo Zagrebački zbor osnovano je 1909. s ciljem unapređenja trgovine i povećanja prometa stranaca u Zagrebu. Godine do Prvoga svjetskog rata obilježene su profiliranjem 
manifestacije, a poslijeratni promijenjeni društveno-politički odnosi, raspad Austro-Ugarske Monarhije i stvaranje novoga ekonomskog područja utjecali su na daljnji razvoj sajma. Temeljna zadaća obnovljenih izložaba od 1922. postaje afirmiranje domaće i inozemne industrije i obrta te gospodarsko upoznavanje i privredno povezivanje dijelova novonastale države koji su prethodno gravitirali različitim tržištima. ${ }^{4}$ Zbor je u međuratnom razdoblju postao jedan od najznačajnijih gospodarskih sajmova u ovom dijelu Europe i imao istaknuto mjesto u privrednoj i društvenokulturnoj povijesti Kraljevine SHS/Jugoslavije. Tijekom 1920-ih poslovanje Zbora nerijetko se modificiralo kako bi se udovoljilo zahtjevima tržišta i inozemnim trendovima, a uspjeh I. medjunarodne izložbe automobila (1924.) najavio je buduću specijalizaciju izložaba. Druga polovina 1920-ih bila je obilježena polarizacijom manifestacije i jačom zastupljenošću inozemnih izlagača na proljetnim, a domaćih na jesenskim izložbama. U 1930-ima Zbor je bio suočen s posljedicama velike ekonomske krize i smanjenjem obujma djelovanja (1930.-1934.), a ponovnu je afirmaciju doživio u razdoblju od 1935. do 1940. kada je preko nacionalnih izložaba postao platformom za gospodarsko i političko nadmetanje europskih velesila. ${ }^{5}$ Sajam je tijekom 1930-ih nastojao zadržati konkurentnu poziciju brojnim zabavnim sadržajima - od modnih i reklamnih revija i različitih atraktivnih izložaba do izbora za najbolje automobile (Concours délégance) - a povećan broj manifestacija rezultirao je i većom narudžbom plakata. ${ }^{6}$

Zbor je od 1922. bio važan naručitelj plakata i imao istaknutu ulogu u populariziranju reklamnog djelovanja na praktičnoj i teorijskoj razini. Već u prvoj polovini 1920-ih na stranicama Službenog vijesnika Zagrebačkog sajma uzoraka objavljivali su se tekstovi o ulozi i važnosti reklame čime su naznačene teme koje će se naći u fokusu stručne javnosti krajem desetljeća. ${ }^{7}$ Pavao Bolkovac, autor znaka ZZ-a i vizualnog identiteta prvih dvaju poslijeratnih sajmova (1922.i 1923.), pisao je o sveprisutnosti reklame u životima građana (»reklama radi, ne miruje«), a najučinkovitijom je smatrao onu koja potiče radoznalost »kupujućeg općinstva« te koncizne i jezgrovite "crtane oglase " koji optimalno variraju sliku i tekst. ${ }^{8}$ Drugi autori težište su stavljali na različite aspekte: reklama je prepoznata kao "najvažniji instrument poslovnoga djelovanja« za koji su važni definiranje ciljane publike, sugestivnost i ponavljanje oglasa, a isticalo se i njezino psihološko djelovanje te potreba informiranja trgovaca o financijskoj isplativosti investiranja u takvu djelatnost. ${ }^{9}$

Dok su tekstovi u zborskom glasilu upućivali na pozitivne rezultate oglašavanja u privredi, važnu ulogu u upoznavanju hrvatske javnosti i umjetnika s dometima suvremenoga europskog i američkoga grafičkog dizajna imala je Međunarodna izložba plakata koja je 1926. održana u sklopu proljetnoga Zagrebačkog zbora i organizirana po uzoru na slične manifestacije $\mathrm{u}$ inozemstvu. ${ }^{10}$ Izložba je potaknula znatnu kritičku recepciju i rezultirala člancima posvećenima percepciji i položaju plakata pri čemu je Stjepan Heimbach pisao o uvjetovanosti jezika plakatne komunikacije diktatom publike, potrebi ispunjavanja estetske i funkcionalne dimenzije, a Iso Kršnjavi o razlikovanju umjetničkog djela i plakata te nužnosti održavanja pobuđenog interesa objavljivanjem novinskih oglasa. ${ }^{11}$ Tijekom idućih godina uslijedile su Film und Foto (1930.) i Izložba reklame (1934.) na kojoj su s teorijskog i praktičnog aspekta prikazani različiti oblici reklamne djelatnosti te predstavljeni brojni plakati i oglasi iz bogate zbirke Theodora Lacha iz Graza.

O važnosti koju je uprava Zbora pridavala propagandnoj djelatnosti svjedoči detaljno razrađen Program propagande za jesenske priredbe 1928. osmišljen u trenutku krize manifestacije zbog novonastalih nepovoljnih političkih okolnosti, ${ }^{12}$ a čiji je zadatak bio animirati izlagače i posjetitelje prije i tijekom trajanja izložbe. Osim »specijalne i individualne propagande« (personaliziranih pismenih poziva, posjeta itd.), posebna pozornost posvećivala se i »općoj reklami« (tisku glasila, plakata, razglednica, letaka, markica itd.). Uz klasične metode oglašavanja planirala se i aeroreklama (bacanje letaka iz aviona), kinoreklama te radioreklama, a o širini reklamnih akcija svjedoče visoke naklade plakata i ostalih popratnih materijala koji su bili tiskani na različitim jezicima. ${ }^{13}$

\section{Počeci oblikovanja vizualnog identiteta i proces narudžbe plakata}

Revitalizacija Zbora nakon Prvoga svjetskog rata bila je popraćena temeljitom organizacijom propagandne djelatnosti, a uprava sastavljena od predstavnika političke, gospodarske i kulturne elite posvećivala je znatnu pozornost načinima i oblicima prezentacije manifestacije u zemlji i u inozemstvu. U jesen 1921. odlučeno je da će se reklama »voditi u vlastitoj režiji «, ${ }^{14}$ a grafičar Pavao Bolkovac angažiran je kao voditelj propagandnih djelatnosti za sajamsku izložbu 1922. ${ }^{15}$ Bolkovac se specijalizirao u Njemačkoj gdje je u velikim izdavačkim kućama radio kao reklamni stručnjak, ${ }^{16}$ a 1922. je oblikovao cjelokupni vizualni identitet Zbora (znak, plakat, kataloge, razglednice i glasnik) te kreirao prepoznatljiv zaštitni znak koji se sa stanovitim modifikacijama koristio tijekom čitavoga međuratnog razdoblja (sl. 1a). Njegov se trademark, po uzoru na mnoge inozemne primjere (Frankfurter International Messe, Utrecht Jaarbeurs), sastojao od početnih slova sajma (ZZ) i petasusa, krilatog šešira rimskog boga trgovine i prometa Merkura koji se često koristio u oglašavanju gospodarskih manifestacija. ${ }^{17}$

Uprava je Bolkovca angažirala kao suradnika i za II. veliki sajam uzoraka 1923., a u detaljno sročenom ugovoru definirane su smjernice oblikovanja vizualnih materijala riječima da »reklama mora pored financijalnoga uspjeha imati 


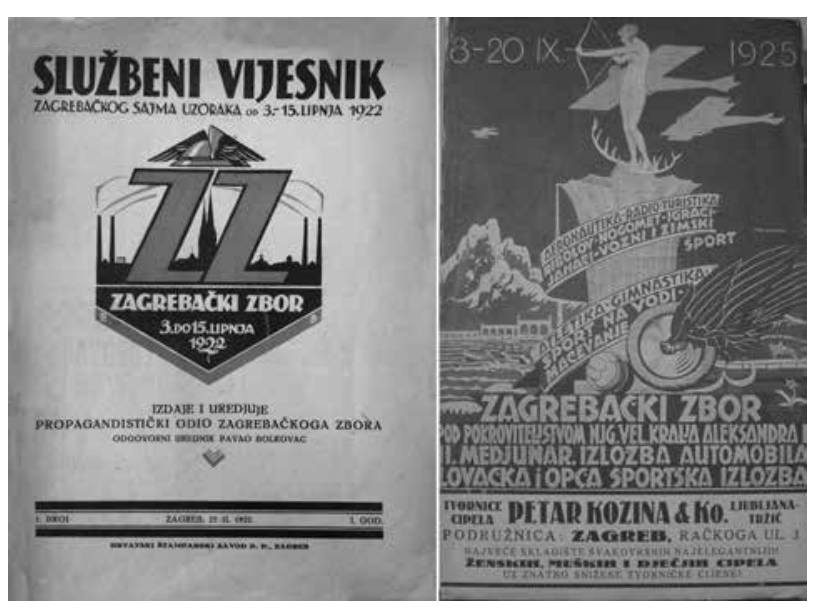

1a. Pavao Bolkovac, Naslovnica Službenog vijesnika Zagrebačkog sajma uzoraka, br. 1, 1922. / Pavao Bolkovac, Cover page of the Official Gazette of the Zagreb Fair, $n .1,1922$

b. Otto Antonini, Naslovnica kataloga Zagrebačkog zbora, II. medjunar. izložba automobila, lovačka i opća športska izložba, 1925. / Otto Antonini, Cover page of the Zagreb Fair catalogue, $2^{\text {nd }}$ International Exhibition of Automobiles, General Sports and Hunting Exhibition, 1925

moderni izgled i smjer i mora da je estetski dotjerana «. ${ }^{18}$ Plakati Zbora iz prve polovine 1920-ih bili su jednostavni i ujednačeno oblikovani, a sadržavali su znak zbora i panoramu Zagreba na kojoj su se isticali toposi grada (katedrala) i simboli industrije (dimnjaci). Gospodarsko usmjerenje ranih izložaba prema domaćoj proizvodnji i narodnim rukotvorinama bilo je jasno signalizirano vizualnim sredstvima - Bolkovac je znak zbora i panoramu 1923. smjestio $\mathrm{u}$ dekorativni okvir ornamentiran motivima etnografske provenijencije, a ista formula primijenjena je i na plakatima proljetnih izložaba 1924. i 1925. Uprava nakon II. velikog sajma uzoraka 1923. nije nastavila suradnju s Bolkovcem, ${ }^{19}$ a kao namještenike Propagandnog odjela angažirala je novinare dr. Franju Deaka i Ćirila Ćudinu. ${ }^{20}$

Proces narudžbe plakata mijenjao se nekoliko puta tijekom međuratnog razdoblja. Zbor nije imao »kućnog dizajnera« nego je naručivao pojedinačne plakate što će u konačnici uvjetovati formalnu i stilsku raznolikost vizualne prezentacije manifestacije. Nakon niza sličnih i po istom modelu oblikovanih rješenja, Zbor je 1925. ambiciozno raspisao veliki javni natječaj za plakat jesenske izložbe. Plakat je odabirao ocjenjivački sud sastavljen od predstavnika ZZ-a i profesora Kr. akademije za umjetnost i umjetni obrt, a po završetku je planirana i izložba pristiglih skica u izlogu knjižare Kugli. ${ }^{21}$ Natječaj nije polučio očekivani uspjeh i uprava je u konačnici naručila novi plakat od Otta Antoninija (1892.-1959.) te u budućnosti odustala od organizacije velikih i skupih natječaja s visokim nagradama. ${ }^{22}$ Antonini je tijekom međuratnog razdoblja u više navrata surađivao sa Zagrebačkim zborom te realizirao niz zborskih plakata. Dok je u oblikovanju vizualnog identiteta ilustrirane revije Svijet (1926.-1932.) utjelovio poželjan životni standard građanskog Zagreba i kreirao lik moderne i samouvjerene žene kao ikone art décoa ${ }^{23}$ na plakatima Zagrebačkog zbora je oscilirao od konvencionalnih rješenja do poigravanja tipografijom, optičkim efektima i simplifikacijom prizora na osnovne motive pojedinih izložaba. U bogatom narativnom rješenju iz 1925. prvi je put u povijesti vizualne prezentacije Zbora primijenio koncept asocijativnog povezivanja motiva s aktualnom temom manifestacije i zastupljenih grana industrije te su guma s Merkurovim krilima, božica Dijana, jelenji rogovi i simboli sporta javnosti nedvosmisleno signalizirali da je riječ o II. međunarodnoj izložbi automobila, lovačkoj i sportskoj izložbi (sl. 1b). ${ }^{24}$

U drugoj polovini 1920-ih i početkom 1930-ih Zbor je putem dnevnih tiskovina pozivao umjetnike da šalju idejne skice, ${ }^{25}$ a pri tome je sugerirao kako bi plakat trebao biti "napadan i lako razumljiv za svakoga« što je nerijetko rezultiralo rješenjima svedenima na ilustriranje glavnih odrednica pojedinog sajma. ${ }^{26}$ Tijekom 1930-ih Zbor je uveo praksu upućivanja poziva samo afirmiranim grafičkim dizajnerima. ${ }^{27}$ Odabir idejnih rješenja bio je pod ingerencijom Ekzekutivnog odbora koji je o plakatima odlučivao na redovitim sjednicama iz čijih je zapisnika vidljivo da su članovi odbora utjecali na izgled plakata, a ponekad davali vlastite prijedloge ili autorima sugerirali promjene kao u slučaju rješenja za XXVII. ZZ (1937.) koji je u maniri art décoa oblikovao Otto Antonini (sl. 4a). ${ }^{28}$ Interes umjetnika je tijekom 1920 -ih i prve polovine 1930-ih bio zamjetno velik te je u prosjeku stizalo između dvadeset $\mathrm{i}$ trideset idejnih rješenja za proljetne ili jesenske sajmove. ${ }^{29}$ Ta se brojka značajno smanjila od sredine 1930-ih jer su umjetnici uvidjeli »da tokom godina izradjuju besplatno mnoge nacrte « te nerijetko ni nakon pismenih i usmenih zamolbi nisu pravovremeno slali svoja idejna rješenja. ${ }^{30}$ Plakati su se tiskali u tehnikama litografije i ofseta te dva formata od kojih je manji bio namijenjen izlaganju u izlozima trgovina, a veći oglašavanju na ulicama, reklamnim stupovima, konstruiranim piramidama ili obeliscima i drugim slobodnim plakatnim površinama. ${ }^{31}$ Tiskali su se u visokim nakladama i na različitim jezicima, ${ }^{32}$ a putem posrednika i filijala Društva za promet stranaca Putnik plasirali diljem Kraljevine SHS/ Jugoslavije i u inozemstvu.

\section{Tipologija plakata Zagrebačkog zbora u međuratnom razdoblju}

Tijekom međuratnog razdoblja organizatori sajmova diljem Europe različito su pristupali oblikovanju vizualnog identiteta svojih manifestacija, a plakati su varirali od korištenja istih rješenja uz modificiranje natpisa i povremenu promjenu dizajna (Leipziger Messe) do poigravanja stiliziranim znakom i tipografijom (Frankfurter Internationale Messe). Stilska heterogenost i brojnost različitih 
tipografskih i figurativnih rješenja obilježavala je vizualni identitet srednjoeuropskih međunarodnih sajmova kao što su Grazer Messe, Budapesti Nemzetközi Vásár, Ljubljanski velesajam i Wiener Internationale Messe čiji su plakati, poput onih Zagrebačkog zbora, bili reprezentativni primjeri vizualne kulture svoga vremena. Širok dijapazon rješenja obilježio je i povijest plakata Zagrebačkog zbora koji su varirali od tradicionalnih, ilustrativnih i narativnih do onih utemeljenih na obrascima karakterističnima za gospodarske manifestacije diljem Europe ili plakata u kojima su umjetnici reinterpretirali avangardni leksik, estetiku art décoa ili klasicističku paradigmu. Tijekom međuratnog razdoblja Zbor je naručio preko šezdeset plakata proljetnih i jesenskih sajmova i specijaliziranih popratnih izložaba koje su oblikovali istaknuti grafički dizajneri poput Sergija Glumca, Otta Antoninija, Emila Vičića, članova Atelijera Tri i drugih, ali i studenti zagrebačke Kr. akademije kojima su ta rješenja nerijetko bila prve važne realizacije (Kornel Becić, Malvine Egersdorfer i dr.).

Vizualna prezentacija predstavljala je važan element izgradnje identiteta manifestacije, a atraktivni su plakati pridonosili komunikacijskoj privlačnosti sajamskih izložaba. Grafička rješenja i odabir motiva nerijetko su pokazivali ključne odrednice aktualnog poslovanja Zbora, a osim umjetničke imaju i dokumentarnu vrijednost te upućuju na važne trenutke sajamske povijesti i predstavljaju svojevrsnu vizualnu kroniku manifestacije.

Plakati Zagrebačkog zbora mogu se prema načinu oblikovanja i komuniciranja poruke, dominantnim motivima ili reinterpretiranju obrazaca karakterističnih za plakate gospodarskih manifestacija podijeliti u nekoliko temeljnih grupa koje se u pojedinim primjerima preklapaju: ${ }^{33}$

1. Plakati bazirani na kombinaciji slova ZZ s Merkurovim atributima (petasus, kaducej) ili grbom Zagreba i panoramom grada u pozadini koji predstavljaju dominantne vizualne elemente, a pojavljuje se u različitim varijantama. Takvo oblikovanje primjenjuje Bolkovac na plakatima 1922. i 1923., a ponavlja se i na rješenjima iz 1924. i 1925. u kojima su zaštitni znak i panorama smješteni u ornamentirane okvire. Pojedini grafičari poigrali su se uobičajenim motivima i reinterpretirali ih na nov način - Peter Kocjančić je primijenio fotomontažu (1934.), Otto Antonini naglasak stavlja na posjetitelja pred kojim se rastvaraju vrata grada simbolički utjelovljena grbom (XXVI. ZZ, 1936.), ${ }^{34}$ dok Sergije Glumac unosi zvučnu dimenziju i spaja panoramsku liniju s trubljama koje nose zastave sa zaštitnim znakom i grbom te u maniri starih sajmova navještavaju održavanje zbora (30. ZZ, 1938.) (sl. 2a). Isti elementi (ZZ, panorama, grb), ali bez Merkurovih atributa, javljaju se i na plakatima krajem međuratnog razdoblja. Nikola Tučemsky je na plakatu jesenskog 32. ZZ-a (1939.) slova ZZ, grb i panoramu

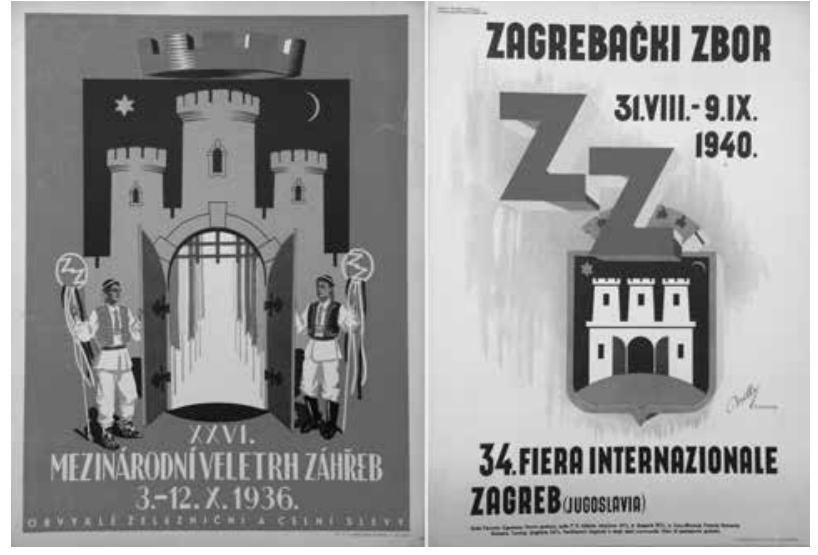

2a. Otto Antonini, XXVI. Mezinárodní veletrh Záhreb, 1936., vl. HR-DAZG-251, sig. 189 / Otto Antonini, XXVI. Mezinárodní veletrh Záhreb, 1936, HR-DAZG-251, call n. 189

b. Anton Brilly, Zagrebački zbor - 34. Fiera internazionale Zagreb, 1940., vl. HR-DAZG-251, sig. 189 / Anton Brilly, Zagreb Fair - 34. Fiera internazionale Zagreb, 1940, HR-DAZG-251, call n. 189

prikazao u povijesnim bojama hrvatske zastave (crveno-bijelo-plavo), ${ }^{35}$ dok je slovenski grafičar Anton Brilly trodimenzionalno interpretirao ZZ i grb grada $u$ povodu jesenskog 34. ZZ-a (1940.) (sl. 2b).

2. Plakati utemeljeni na kombinaciji plošno ili plastički oblikovanih inicijala zbora (ZZ) i motiva koji simboliziraju zastupljene grane industrije ili teme popratnih izložaba (Salon automobila, Izložba peradi, kunića, golubova itd.).

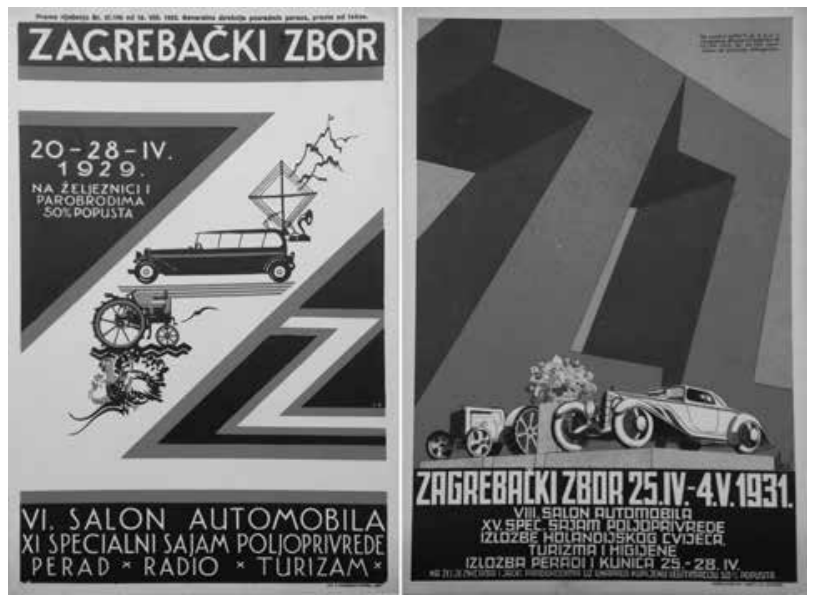

3a. Otto Antonini, Zagrebački zbor - VI. salon automobila, XI. specialni sajam poljoprivrede, perad, radio, turizam, 1929., vl. HRDAZG-251, sig. 190 / Otto Antonini, Zagreb Fair $-6^{\text {th }}$ Automobile Show, $11^{\text {th }}$ Specialized Fair of Agriculture, Poultry, Radio, Tourism, 1929, HR-DAZG-251, call n. 190

b. Kornel Becić, Zagrebački zbor - VIII. salon automobila, XV. spec. sajam poljoprivrede, izložbe holandijskog cvijeća, turizma i higijene, 1931., vl. HR-DAZG-251, sig. 187 / Kornel Becić, Zagreb Fair $-8^{\text {th }}$ Automobile Show, $15^{\text {th }}$ Specialized Fair of Agriculture, Exhibitions of Dutch Flowers, Tourism and Hygiene, 1931, HRDAZG-251, call n. 187 


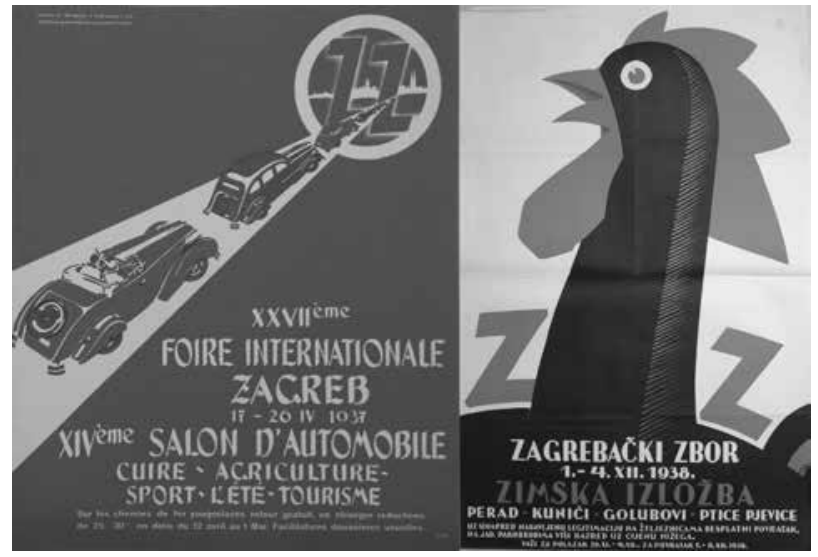

4a. Otto Antonini, XXVII ème Foire internationale Zagreb - XIVème Salon d'automobile, 1937., vl. HR-DAZG-251, sig. 187 / Otto Antonini, XXVII ${ }^{\text {ème }}$ Foire internationale Zagreb - XIVème Salon d'automobile, 1937, HR-DAZG-251, call n. 187

b. Zagrebački zbor - Zimska izložba, 1938., vl. HR-DAZG-251, sig. 191 / Zagreb Fair - Winter Exhibition, 1938, HR-DAZG-251, call n. 191

Riječ je o najčešćem tipu plakata koji je realiziran u nizu varijanti - od stiliziranih rješenja reduciranih na slova ZZ i simbole tehnologije i privrede (Otto Antonini, XI. ZZ, 1929.) do arhitektonskih ili plošnih ZZ s dopadljivim domaćim životinjama (rješenja Kornela Becića iz 1930., Atelijera Tri iz 1937., Otta Antoninija iz 1938.) ili automobilima (sl. 3ab, 4b). Dio plakata prikazuje modele luksuznih automobila koji utjelovljuju poželjan životni standard i interes posjetitelja usmjeravaju na popularni salon automobila (rješenja Vladimira Mirosavljevića iz 1930., Sergija Glumca iz 1938. i Atelijera Tri iz 1939.).

3. Plakati u kojima su izostavljena slova ZZ, a tema sajma simbolički je posredovana prepoznatljivim identifikacijskim faktorima.

Andrija Maurović je 1927. posegnuo za »kolažnim« principom, a glave automobilista, seljaka i radiooperatera prikazane na plakatu upućivale su na glavne izložbene artikle toga proljetnog sajma. Tip je bio uobičajen za plakate popratnih izložaba poput Izložbe holandijskog cvijeća (Maksimilijan Vanka, 1931.) ili Velike zanatske izložbe (Ljubo Babić, 1933.), ${ }^{36}$ te čest u realizacijama Sergija Glumca koji je ujedno autor najvećeg broja zborskih plakata u međuratnom razdoblju (III. internacionalna izložba pasa, Jadranska izložba itd.) (sl. 10b). ${ }^{37}$

4. Plakati koji vizualnim sredstvima konotiraju šira značenja:

a) oblikovanjem se sugerira međunarodni karakter manifestacije ili njezina uloga u promoviranju pojedinih privrednih grana. Ernest Tomašević je 1924. slova ZZ oblikovao od automobila/zastava različitih svjetskih država čime je naglasio međunarodni karakter prve
Internacionalne izložbe automobila, manifestacije koja će u međuratnom razdoblju postati najvećom uspješnicom ZZ-a i pridonijeti istaknutoj ulozi Zagreba u promoviranju automobilske industrije u Kraljevini SHS/Jugoslaviji. Uspješno artdécoovsko rješenje Božidara Kocmuta za 14 . ZZ na nekoliko je razina korespondiralo $s$ aktualnim položajem i značenjem zbora - odabir motiva bio je komplementaran ključnim događanjima koja su obilježila zagrebačku jesen 1930. (međunarodni kongres graditelja i Graditeljska izložba), a dramatično (»filmsko«) osvjetljenje prikazanih nebodera u obliku slova ZZ koji streme u visinu simbolički je označavalo težnje Zbora (sl. 5b).

b) oblikovanjem se ilustrira moto manifestacije. Marcel Fišer je inicijalima zbora dao antropomorfna obilježja Merkura koji naganja kovanicu te u vrijeme najveće ekonomske krize duhovito prikazao znakoviti moto proljetnog sajma 1932. (»Novac mora kolati«).

c) korištenje motiva hrvatskog folklora i etnografske provenijencije trebalo je potaknuti identifikaciju ciljanih posjetitelja i uputiti na značenje sajma u lokalnim okvirima. Oko 1927. dolazi do polarizacije ZZ-a i usmjerenja inozemnih posjetitelja prema proljetnom, a domaćih prema jesenskom sajmu. Sukladno tomu, glavni akteri rujanskih izložaba postaju muškarci i žene u nošnjama što je vidljivo na plakatu Željka Hegedušića za 8. ZZ (1927.) $)^{38}$ te rješenju Zdenke Sertić i Maksimilijana Vanke za 10. ZZ (1928.) (sl. 5a).

d) prikaz putokaza i automobila/vlaka koji jure prema Zagrebu imaju agitacijsko svojstvo i upućuju na privlačnost manifestacije - npr. plakati Lenarda (1935.), Glumca (1936.) i Antoninija (1937.).

5. Rješenja u kojima je dominantan motiv plakata figurativni ili stilizirani lik rimskog boga trgovine i prometa Merkura, odnosno njegovi atributi u kombinaciji s inicijalima ZZ ili bez njihova naglašavanja.

Krilati šešir ili kaciga javlja se u oblikovanju vizualnog identiteta zbora već na plakatima prvih poslijeratnih izložba. Merkurov lik prvi put primjenjuje Atelier Fortuna za plakat 6. ZZ-a (1926.), a u stiliziranoj varijanti koristi i Ljubo Babić za plakat I. zagrebačkog božićnog zbora (1927.). Emil Vičić je tijekom 1930-ih učestalo koristio Merkurov lik i atribute koji su se u različitim varijantama javljali i kod drugih dizajnera. ${ }^{39}$

6. Rješenja zasnovana na poigravanju tipografijom ili uvođenju avangardnoga grafičkog oblikovanja u domenu komercijalnoga tržišnog komuniciranja - npr. primjena fotomontaže (Peter Kocjančić, XXII. ZZ, 1934.), postavki nove tipografije (Sergije Glumac, XII. ZZ, 1929.) itd. (sl. 5c). 


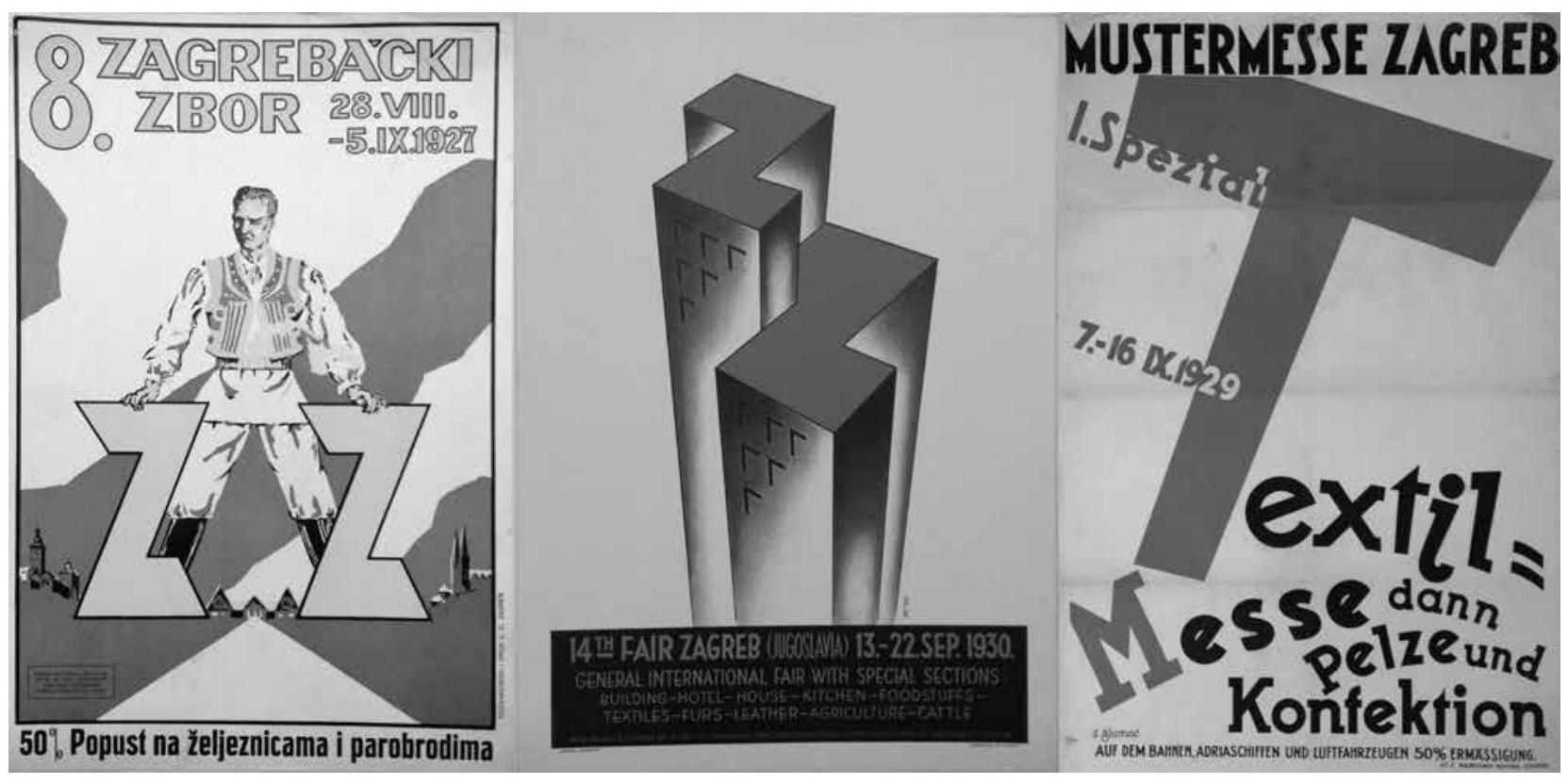

5a. Željko Hegedušić, 8. zagrebački zbor, 1927., vl. HR-DAZG-251, sig. 187 / Željko Hegedušić, $8^{\text {th }}$ Zagreb Fair, 1927, HR-DAZG-251, call n. 187

b. Božidar Kocmut, $14^{\text {th }}$ Fair Zagreb, 1930., vl. HR-DAZG-251, sig. 187 / Božidar Kocmut, $14^{\text {th }}$ Fair Zagreb, 1930, HR-DAZG-251, call n. 187 c. Sergije Glumac, Mustermesse Zagreb - I. Spezial Textil-Messe, 1929., vl. HR-DAZG-251, sig. 193 / Sergije Glumac, Mustermesse Zagreb - I. Spezial Textil-Messe, 1929, HR-DAZG-251, call n. 193

\section{Zaboravljeni autori plakata Zagrebačkog zbora}

Tijekom 1930-ih pojedinačne plakate Zagrebačkog zbora oblikovali su danas zaboravljeni grafičari i grafički dizajneri čija se imena ne nalaze u enciklopedijskim izdanjima niti spominju u pregledima povijesti hrvatskog plakata. Među njima ističu se Kornel Becić, Marcel Fišer, Malvine Egersdorfer i Zvonimir Lenard koji su u razdoblju od 1930. do 1935. oblikovali neke od najuspješnijih zborskih plakata. ${ }^{40}$

Kornel Becić pl. Rustenberg (1910.-1999.) školovao se na zagrebačkoj Kr. akademiji za umjetnost i umjetni obrt gdje je od 1930. do 1933. pohađao slikarsku školu Joze Kljakovića i Ljube Babića. ${ }^{41}$ Tijekom studija (1930.-1932.) oblikovao je efektne i dopadljive plakate za pet izložaba Zagrebačkog zbora koje obilježava dokidanje dvodimenzionalnosti i snažan prodor u prostor te jasna podjela u dvije zone - usku donju u kojoj se nalaze natpisi i dominantnu gornju u kojoj kombinira monumentalna voluminozna, arhitektonski riješena slova ZZ i realistički prikaz glavnih "protagonista" pojedinog sajma (životinja, automobila i gospodarskih strojeva ili sv. Nikole) (sl. 6ab, 7a)..$^{42}$ Među zborskim plakatima ističe se uspješno artdécoovsko rješenje za XVIII. ZZ (1932.) na kojemu Becić primjenjuje koncept popularan u oglašavanju inozemnih gospodarskih manifestacija te simulira pogled iz zraka i naglašenom mo- numentalnom formom (uskličnikom s utisnutim slovima ZZ) vizualnim sredstvima upućuje na lokaciju zbora (sl. 8). Nakon prekida studija na Akademiji, Becić je još niz godina radio u Hrvatskoj kao grafički dizajner i ilustrator, ${ }^{43}$ a 1935. je realizirao humorističan plakat koji je pratio Ribarski sajam te tekstom i dopadljivom slikom zagovarao veću potrošnju ribe (sl. 7b). ${ }^{44}$ Godine 1933. ilustrirao je četiri slikovnice za djecu Vladimira Prebega u izdanju Knjižare St. Kugli ${ }^{45}$ u kojima je stvorio prepoznatljive simpatične, realistički i voluminozno oblikovane dječje likove koji će biti karakteristični i za njegov kasniji dizajnerski i slikarski opus. ${ }^{46}$ Becićev leksik blizak je popularnoj ikonografiji onodobnih stripova i disneyjevskoj estetici, a pojedina rješenja odabirom likova i načinom prikazivanja srodna su reklamama za proizvode široke potrošnje (Niveu, Persil itd.) koji su 1930-ih nudili optimističnu sliku suvremenoga konzumerističkog društva. Tijekom druge polovine 1930-ih Zbor je Beciću kao istaknutom grafičkom dizajneru redovito upućivao pozive za oblikovanje zborskih plakata. ${ }^{47}$ Nakon odlaska iz Hrvatske, u rodnom Grazu se pod imenom Cornel von Becic-Rustenberg nastavio baviti slikarstvom i grafičkim dizajnom te oblikovao neke od ikoničkih turističkih plakata (Steiermark). ${ }^{48}$

Zaboravljeno ime u povijesti hrvatskoga grafičkog dizajna je i Marcel Fišer koji je artdécoovskim ilustracijama i oglasima 1932. obilježio grafičko oblikovanje popularne revije Cinema. Fišer je u grafički dizajn prenio estetiku ka- 

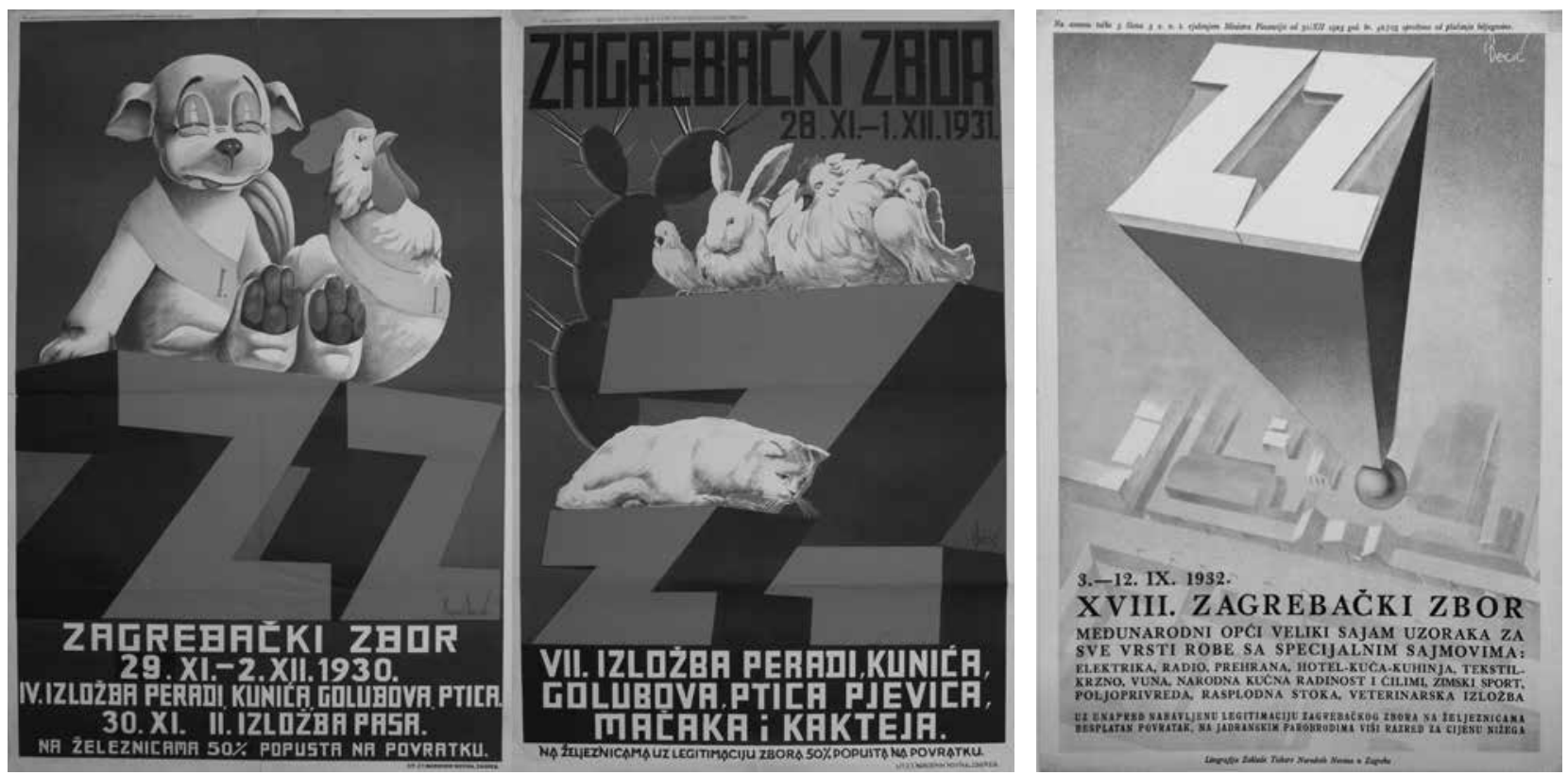

6a. Kornel Becić, Zagrebački zbor - IV. izložba peradi, kunića, golubova, ptica, II. izložba pasa, 1930., vl. HR-DAZG-872, Zbirka tiskovina / Kornel Becić, Zagreb Fair $-4^{\text {th }}$ Exhibition of Poultry, Rabbits, Pigeons, Birds, $2^{\text {nd }}$ Dog Show, 1930, HR-DAZG-872, Publication

8. Kornel Becić, XVIII. zagrebački zbor, 1932., vl. HR-DAZG-251, sig. 187 / Kornel Becić, $18^{\text {th }}$ Zagreb Fair, 1932, HR-DAZG-251, call n. 187 collection

b. Zagrebački zbor - VII. izložba peradi, kunića, golubova, ptica pjevica, mačaka i kakteja, 1931., vl. HR-DAZG-251, sig. 191 / Zagreb Fair - $7^{\text {th }}$ Exhibition of Poultry, Rabbits, Pigeons, Song-Birds, Cats and Cactuses, 1931, HR-DAZG-251, call n. 191

rakterističnu za druge medije poput filma ili fotografije te njegova rješenja nerijetko obilježavaju naglašeni svjetlosni kontrasti i arhitektonika ili dekorativnost scene koji su uobičajeni za scenografije hollywoodskih filmova ili pozadine fotografija i ilustracija objavljivanih na stranicama popularnih inozemnih međuratnih mondenih revija. Takav pristup primijenio je u oblikovanju naslovne stranice priloga Revija Zagrebačkog zbora u jesen 1932., dok je za proljetni ZZ 1932. izveo spomenuto netipično rješenje s antropomorfnim inicijalima zbora (sl. 9ab).

Danas nepoznata Malvine (Malvinia) Egersdorfer (1912.-1945.) oblikovala je rješenja za proljetni i jesenski

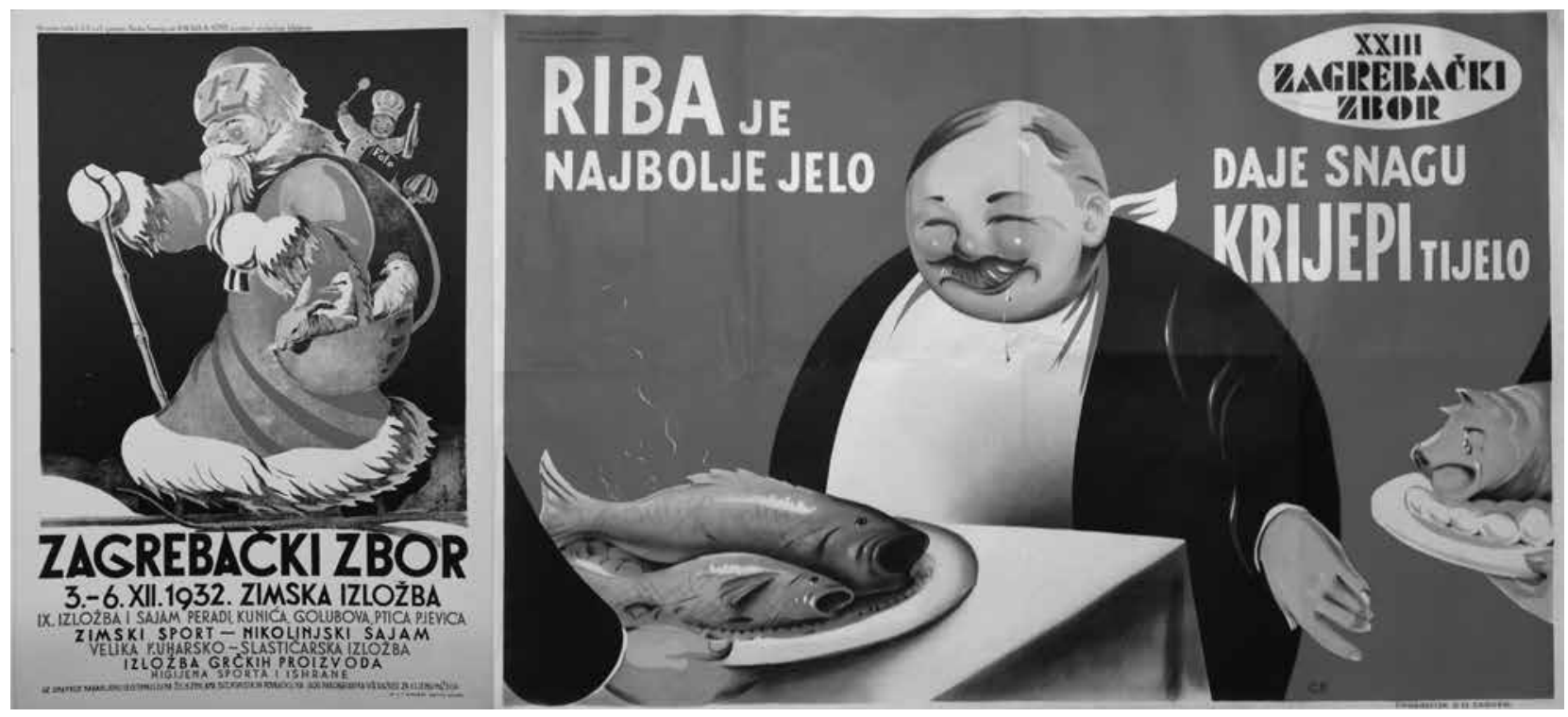

7a. Kornel Becić, Zagrebački zbor - Zimska izložba, 1932., vl. HR-DAZG-251, sig. 187 / Kornel Becić, Zagreb Fair - Winter Exhibition, 1932, HR-DAZG-251, call $n .187$

b. Popratni plakat XXIII. zagrebačkog zbora, 1935., vl. HR-DAZG-251, sig. 192 / Poster accompanying the 23 ${ }^{\text {rd }}$ Zagreb Fair, 1935, HRDAZG-251, call n. 192 


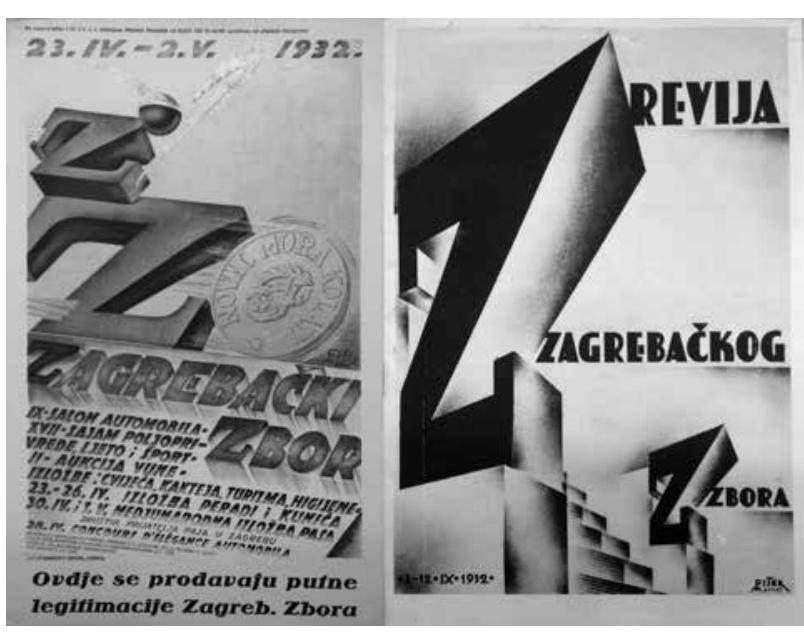

9a. Marcel Fišer, Zagrebački zbor, 1932., vl. HR-DAZG-251, sig. 188 / Marcel Fišer, Zagreb Fair, 1932, HR-DAZG-251, call n. 188 b. Revija Zagrebačkog zbora, u: Cinema, VI/18 (1932.), 55 / Zagreb Fair Review, in: Cinema VI/18 (1932), 55

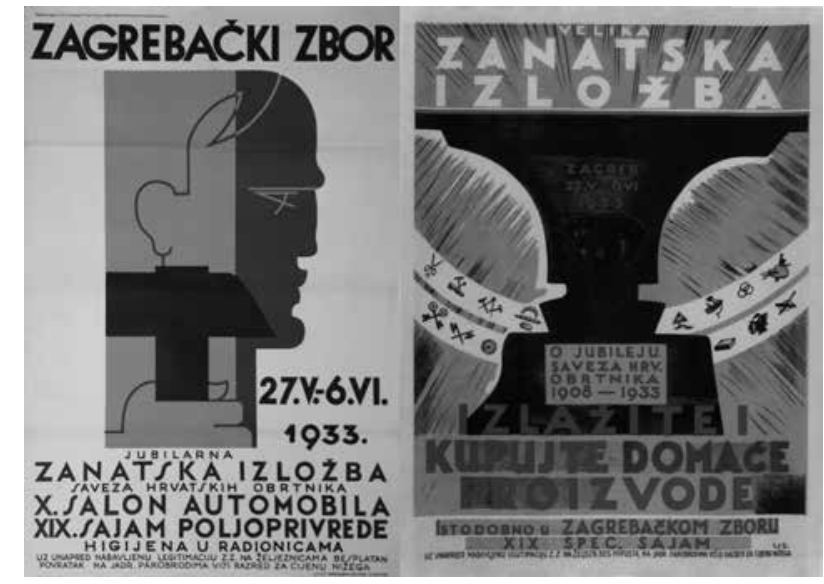

10a. Malvine Egersdorfer, Zagrebački zbor - Jubilarna zanatska izložba Saveza hrvatskih obrtnika, 1933., vl. HR-DAZG-251, sig. 190 / Malvine Egersdorfer, Zagreb Fair - Jubilee Artisan Exhibition of the Association of Croatian Craftsmen, 1933, HR-DAZG-251, call n. 190

b. Ljubo Babić, Velika zanatska izložba, 1933., vl. HR-DAZG-251, sig. 191 / Ljubo Babić, Big Artisan Exhibition, 1933, HR-

DAZG-251, call n. 191

zbor $1933 .{ }^{49}$ te je uz Zdenku Sertić jedina žena koja je dizajnirala zborske plakate. Školovala se za slikaricu kod Kljakovića i Omera Mujadžića na zagrebačkoj Akademiji u isto vrijeme kada i Becić (1930.-1932.). ${ }^{50}$ Njezine plakate odlikuje puristički leksik, stroga geometrija i princip redukcije te jednostavnost i svedenost na igru ploha i linija. Lice radnika s čekićem na plakatu proljetnog zbora 1933. korespondira s glavnom manifestacijom sajma (Jubilarnom zanatskom izložbom) čiji je plakat oblikovao Babić, ali Egersdorfer za razliku od realističkoga ilustrativnog Babi-

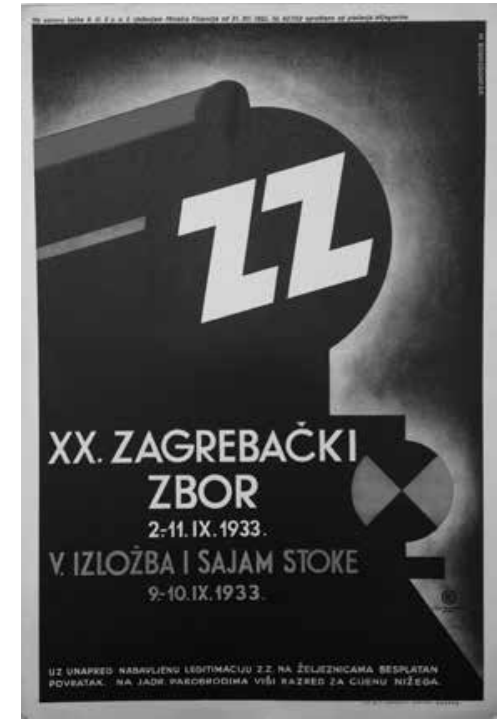

11. Malvine Egersdorfer, XX. zagrebački zbor, 1933., vl. HRDAZG-251, sig. 187 / Malvine Egersdorfer, $20^{\text {th }}$ Zagreb Fair, 1933, HR-DAZG-251, call n. 187

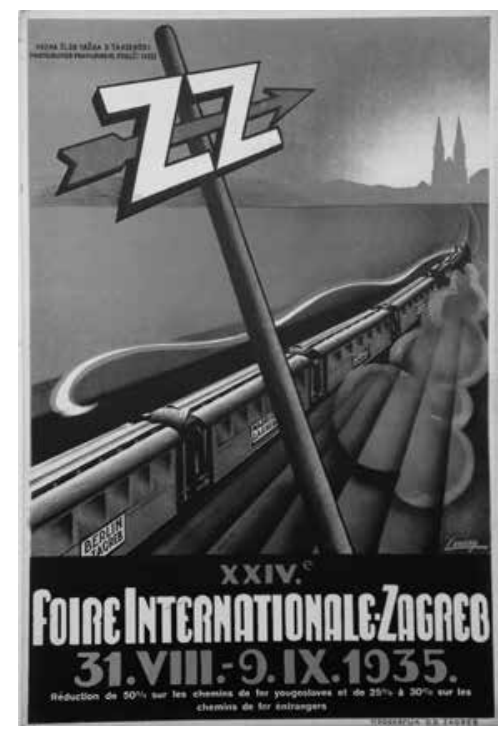

12. Zvonimir Lenard, XXIVe Foire Internationale Zagreb, 1935., vl. HR-DAZG-251, sig. 187 / Zvonimir Lenard, XXIV Foire Internationale Zagreb, 1935, HR-DAZG-251, call n. 187

ćeva rješenja primjenjuje govor redukcije koji derivira iz avangardnih pravaca (sl. 10a). Oblikovni inventar avangardne provenijencije, geometrizacija i simplifikacija obilježila je njezin artdécoovski plakat za jesenski zbor 1933. na kojem osvijetljeni vagon dijagonalno "ulazi« $\mathrm{u}$ kadar te utjelovljuje modernističku sklonost stroju i pokretu (sl. 11). Unatoč uspješnim grafičkim ostvarenjima, Malvine Egersdorfer je uskoro najvjerojatnije napustila umjetnički poziv. Nakon udaje za Herberta Woschnagga (Vošnjaga), vlasnika najveće tvornice kože u jugozapadnoj Europi, posvetila se 
putovanjima, mondenom životu i uređivanju njihove Vile Široko u Šoštanju, a tijekom Drugoga svjetskog rata radila je u Crvenom križu i surađivala s partizanima zbog čega su je Nijemci uhapsili i 1945. strijeljali. ${ }^{51}$

Zvonimir Lenard je nauk iz grafičke struke stekao u tiskari V. Rožankowsky i drug, ${ }^{52}$ a tijekom međuratnog razdoblja bio je cijenjen grafičar iako nije pohađao Akademiju. Njegovo rješenje jednoglasno je odabrano između 23 skica za plakat jesenskog XXIV. ZZ- $a,{ }^{53}$ a obilježava ga poigravanje motivima koji su bili uobičajeni u oblikovanju plakata gospodarskih manifestacija - prikaz jurećeg vlaka kojeg prema cilju usmjerava stup s natpisom ZZ i strelicom. Za razliku od stiliziranoga, plošnog rješenja Malvine Egersdorfer, Lenard sučeljavanjem dijagonala vlaka i stupa postiže snažan skok u dubinu, a natpisima inozemnih destinacija na vagonima $i$ radirajućim linijama pare dodatno potencira internacionalni karakter zbora te brzinu i efikasnost kao poželjne osobine suvremenog doba (sl. 12).

$$
* * *
$$

Tijekom međuratnog razdoblja Zagrebački zbor je svojom izlagačkom i naručiteljskom politikom imao značajnu ulogu u promoviranju grafičkog dizajna namijenjenog tržištu na teorijskoj i praktičnoj razini. Prve poslijeratne sajmove obilježilo je vizualno profiliranje manifestacije, a prezentaciji Zbora u domaćim i inozemnim okvirima krajem 1920-ih i tijekom 1930-ih pridonijeli su vodeći i manje poznati grafički dizajneri onoga vremena. U razdoblju kada su na polju tržišnih komunikacija i u oglašavanju inozemnih tvrtki koje su djelovale na području Kraljevine SHS dominirali uvezeni oglasi i plakati, Zagrebački zbor postao je poligonom za oblikovanje i prezentaciju modernoga grafičkog dizajna. Dijapazon rješenja koja su pridonijela vizualnoj prepoznatljivosti Zbora varirao je od konvencionalnih i narativnih do vrhunskih primjera art décoa ili povremene upotrebe obilježja avangardne umjetnosti u domeni tržišnog komuniciranja. Pojedini realizirani plakati svjedoče o visokoj kvaliteti međuratnoga domaćeg grafičkog dizajna koji se reprezentativnošću te uspješnošću oblikovanja i komuniciranja poruke može mjeriti s vrhunskim europskim primjerima. Uspješnu produkciju pratila je i adekvatna kritička recepcija, a suvremenici su »reklamnu umjetnost« smatrali značajnim segmentom onodobne likovne scene i o njoj pisali na stranicama stručnih časopisa i dnevnih tiskovina. ${ }^{54}$ Grafičari koji su se bavili »umjetničkom reklamom« poput Glumca, Gavranića, Kocmuta i braće Mirosavljević bili su prepoznati kao istaknuti protagonisti suvremene scene čiji su plakati za različite manifestacije, pa i za Zagrebački zbor, "takove radnje, na kojima bi im mnogi europski reklamni umjetnik mogao pozavidjeti ${ }^{55}$

\section{BILJEŠKE}

1 Plakati Zagrebačkog zbora iz Kabineta grafike HAZU prvi su put predstavljeni u: RENATA GOTTHARDI-ŠKILJAN, Plakat u Hrvatskoj do 1941., katalog izložbe, Kabinet grafike JAZU, Zagreb, 3. 2. - 8. 3. 1974., te ponovljeni u: VESNA KEDMENEC KRIŽIĆ, Plakati Zagrebačkog zbora od 1910.-1940. iz fundusa Kabineta grafike, katalog izložbe, Kabinet grafike HAZU, Zagreb, rujan 2002. U proteklih desetak godina organizirano je nekoliko prigodnih izložaba zborskih plakata bez popratnih publikacija (npr. Plakati Zagrebačkog zbora u sklopu Tjedna arhiva 2003.). Plakati Zbora bili su predstavljeni i na brojnim kulturološkim izložbama, npr. Umjetnost uvjeravanja: oglašavanje u Hrvatskoj 1835.-2005., katalog izložbe, (ur.) Feđa Vukić, Muzej za umjetnost i obrt, Zagreb, 12. 6. - 16. 7. 2006.

2 FEĐA VUKIĆ, Stoljeće hrvatskog dizajna, Meandar, Zagreb, 1996.; LADA KAVURIĆ, Hrvatski plakat do 1940., Institut za povijest umjetnosti; NSK; Horetzky, Zagreb, 1999.

3 JASNA GALJER, Plakati za Zagrebački zbor 1926. (Prilog redefiniranju povijesti hrvatskog plakata), Radovi Instituta za povijest umjetnosti, 28 (2004.), 336-347; LOVORKA MAGAŠ BILANDŽIĆ, Lik Merkura u hrvatskom grafičkom dizajnu između dva svjetska rata, u: Metamorfoze mita. Mitologija u umjetnosti od srednjeg vijeka do moderne: zbornik radova znanstvenog skupa Dani Cvita Fiskovića, (ur.) Dino Milinović, Joško Belamarić, Odsjek za povijest umjetnosti Filozofskog fakulteta Sveučilišta u Zagrebu, Zagreb, 2012., 169-184.

4 IVO BELIN, Značenje zagrebačkog velikog sajma, Službeni vijesnik Zagrebačkog sajma uzoraka, 3 (1922.), bez paginacije.

5 Više vidjeti u: GORAN ARČABIĆ, Zagrebački zbor kao poveznica hrvatskog i europskog gospodarstva (1922.-1940.), Srednja Europa; Muzej grada Zagreba, Zagreb, 2013.

6 Godine 1938. realizirano je čak sedam različitih plakata koje su oblikovali Sergije Glumac (29. i 30. ZZ, Jadranska izložba), Otto Antonini (Zimska izložba), P. Sorokin (VIII. izložba vina) te Edo Murtić i nepoznati autor (Velika obrtnička izložba).

7 Ponajprije kroz djelovanje Miroslava Fellera i Zavoda za znanstveno proučavanje reklame i umjetničku reklamnu produkciju Imago. Više vidjeti u: LOVORKA MAGAŠ, Reklamni zavod Imago i komercijalni grafički dizajn u Hrvatskoj 1920-ih, Peristil, 51 (2008.), 99-118.

8 PAVAO BOLKOVAC, Trgovac - reklama - kupac, Službeni vijesnik Zagrebačkog sajma uzoraka, 6 (1922.), bez paginacije.

9 SIMO BULJEVIĆ, Tehnika i ekonomija reklame, Zagrebački zbor: privredna smotra, 2 (1924.), bez paginacije; VLADIMIR KESTERČANEK, Troškovi reklame, Zagrebački zbor: privredna smotra, 4 (1924.), bez paginacije.

10 Više vidjeti u: JASNA GALJER (bilj. 3).

11 STJEPAN HEIMBACH, Plakat, Grafička revija, 5-6 (1926.), 86-87; ISO KRŠNJAVI, Izložba plakata u zboru, Vijenac, 7 (1926.), 182-183.

12 Smanjenje državnih poticaja i subvencija za željeznice te zategnuti odnosi s Beogradom koji je planirao pokrenuti vlastiti sajam negativno su se odrazili na uspjeh proljetnog sajma 1928. Usp. GORAN ARČABIĆ (bilj. 5), 79-80.

13 Državni arhiv u Zagrebu, Fond 251. Zagrebački zbor (dalje: HRDAZG-251), sig. 10. Zapisnici sjednica Upravnog, Izvršnog i Tehničkog i financijskog odbora 1921.-1945., Program propagande za jesenje priredbe Zagrebačkog zbora godine 1928. - Planirano je po 10000 velikih i malih plakata, 1000 transparentnih plakata na domaćim i stranim jezicima (njemačkom, francuskom, češkom i engleskom), te 50000 prospekata i 100000 letaka.

14 HR-DAZG-251-10, Zapisnik sjednice upravnog odbora ZZ (dalje: ZSUP), 29. 10. 1921.

15 HR-DAZG-251-10, ZSUP, 5. 1. 1922. - Stiasni izvješćuje da je postignut dogovor s Bolkovcem.

16 Buchdruck-Fachmann, Österreichisch-Ungarische Buchdrucker-Zeitung, 36 (1915.), 4. - U osobnom oglasu Paul Bolkovac (32) iz Valpova traži namještenje u struci i navodi da je iskusan tipograf i propagandist. 
17 Više o Bolkovcu i korištenju Merkurova lika u grafičkom dizajnu Zbora vidjeti u: LOVORKA MAGAŠ BILANDŽIĆ (bilj. 3).

18 HR-DAZG-251, sig. 151. Dosje Pavao Bolkovac (dalje: DPB), Nacrt ugovora.

19 HR-DAZG-251-151, DPB, Pismo Pavla Bolkovca Predsjedništvu ZZ, 22. 9. 1923. - Do neslaganja je došlo zbog djelokruga Bolkovca i financijskih pitanja.

20 HR-DAZG-251, 6. Zapisnici sjednica Ekzekutivnog odbora 1922.-1926. (dalje: ZSEO), 24. 1. 1924.

21 Arhiv Akademije likovnih umjetnosti, Zagreb (dalje: Arhiv ALU), Opći spisi 1925., Br. 218/1925. Natječaj za izradbu plakata za Jesensku izložbu ZZ, 27. 6. 1925. - Plakate su žirirali predsjednik ZZ-a (F. Prevedan), potpredsjednici (S. D. Aleksander, M. Šarčević) i odbornik Ignjat Fischer te umjetnici M. Cl. Crnčić, R. Frangeš, M. Vanka, V. Becić i I. Kerdić, a nagrade su iznosile 6000, 4000 i 2000 dinara.

22 HR-DAZG-251-10, ZSEO, 21. 9. 1938.

23 Više o Antoninijevu oblikovanju časopisa Svijet vidjeti u: ŽELJKA KOLVESHI, Otto Antonini: Zagreb $i$ »Svijet« / „Svijet « $i$ Zagreb dvadesetih..., studeni-prosinac 2006., Muzej grada Zagreba, Zagreb, 2006.

24 Plakat nije publiciran u stručnoj literaturi, a reprodukcija rješenja objavljena je na naslovnici Službenog kataloga jesenske izložbe (tada je bilo uobičajeno da se na naslovnici kataloga reproducira plakat aktualne izložbe). U literaturi se na osnovi predloška koji se čuva u Grafičkoj zbirci NSK netočno navodilo da je Sergije Glumac autor plakata za jesensku izložbu 1925.

25 Plakat za Zagrebački Zbor, Novo doba, IX/85 (13. travnja 1926.), 5. - Poziv je unaprijed definirao različite parametre poput dimenzija, boje i natpisa.

26 Nacrt plakata za proljetni Zagrebački zbor, Večer, XII (20. siječnja 1931.), 2.

27 HR-DAZG-251-10, ZSEO, 21. 9. 1938.

28 HR-DAZG-251-10, ZSEO, 15. 2. 1937. - Ako nisu bili zadovoljni pristiglim rješenjima, tražili su nove skice, a za sajamski plakat 1937. odbornik Karlović je predložio »cestu po kojoj automobili jure u Zagreb, čija silhueta se vidi u pozadini« te je već na idućoj sjednici prihvaćeno rješenje Otta Antoninija nastalo na osnovi te ideje (ZSEO, 24. 2. 1937.).

29 Godine 1934. pristiglo je 26 skica za jesenski sajam, 1937. svega četiri za Izložbu peradi, a 1940. devet za proljetnu izložbu. - Vidjeti: HRDAZG-251-10, ZSEO, 13. 7. 1934.; 5. 11. 1937.; 28. 2. 1940.

30 HR-DAZG-251-10, ZSEO, 21. 9. 1938. - Zbor je otkup jednog nacrta plaćao 1500 dinara.

31 Veliki plakati tiskali su se u približnim dimenzijama $95 \times 63 \mathrm{~cm}$, a mali $28 \times 23 \mathrm{~cm}$. - HR-DAZG-251, 126. Korespondencija, Dopis ZZ Jugoslavenskoj štampi, 28. 7. 1934.

32 Ibid. - ZZ je za jesensku izložbu 1934. od Jugoslavenske štampe naručio 12000 plakata i 100000 markica po nacrtu Petera Kocjančića.

$33 \mathrm{U}$ radu se zbog ograničenog prostora ne reproduciraju niti detaljnije obrađuju plakati koji su već objavljeni u literaturi navedenoj u bilješkama 1-3. Manji dio plakata objavljenih u ovom radu je kao ilustrativan materijal i bez navođenja autora rješenja objavljen u: GORAN ARČABIĆ (bilj. 5), odnosno na internetskim stranicama Državnog arhiva u Zagrebu (URL: http://www.daz.hr/izlozba_zbor_galerija.html, 6. 2. 2014.).

34 Nesignirani plakat za jesenski zbor dosad nije bio objavljen u literaturi. Podatak o autoru iz: HR-DAZG-251-10, ZSEO, 13. 3. 1936.

35 Odbor je izabrao njegovo rješenje između sedam predloženih idejnih skica. - HR-DAZG-251-10., ZSEO, 6. 7. 1939. Gotthardi-Škiljan, Kedmenec Križić i Kavurić navode da je plakat djelo Nikole Tučana.

36 Babićev plakat je u vrijeme kulminacije ekonomske krize u Kraljevini Jugoslaviji prikazivao nakovanj (simbol rada) na pijedestalu »kao svetinju « koja osvjetljava simbole zanatstva, a o njegovoj komunikacijskoj i agitacijskoj (»Izlažite i kupujte domaće«) uspješnosti pisalo se i na stranicama onodobnog tiska. - Umjetnički plakat za zanatsku izložbu u Zagrebu, Novo doba, XVI/74 (29. ožujka 1933.), 5.

37 Više o plakatima Sergija Glumca i njegovoj suradnji sa Zagrebačkim zborom vidjeti u: LOVORKA MAGAŠ BILANDŽIĆ, Sergije Glumac - život $i$ djelo, doktorska disertacija, Filozofski fakultet Sveučilišta u Zagrebu, Zagreb, 2012.

38 Plakat prikazuje muškarca u nošnji koji se oslanja na monumentalna slova ZZ te optički povezuje grad i selo. Hegedušićevo autorstvo spominje se u dokumentaciji ZZ-a, a skicu je trebao izvesti uz stanovite izmjene. - HR-DAZG-251, 7. Zapisnik sjednica Ekzekutivnog odbora (1926.-1931.), 15.6. 1927.

39 Detaljno o motivu Merkura na plakatima ZZ-a vidjeti u: LOVORKA MAGAŠ BILANDŽIĆ (bilj. 3).

40 Manje uspješna narativna rješenja za popratne priredbe Zbora oblikovali su Strmecki za Veliku izložbu i sajam rasplodne stoke na ZZ-u (1933.) i P. Sorokin za VIII. izložbu i sajam vina (1938.).

41 Arhiv ALU, Matični list br. 234. Kornel K. Becić pl. Rustenberg. - Rodio se 7. prosinca 1910. u Grazu u kojemu je završio pet razreda Zemaljske više realke. Na akademiji je pohađao Nauku o slogovima (B. Šenoa), Ornamentalno crtanje, Plakat i Grafiku (T. Krizman) te Ukrasno i Ornamentalno pismo (O. Höcker). Zbog nepohađanja nastave bio je nekoliko puta opomenut te mu je uskraćen upis u zimski semestar 1933./34.

42 Izradio je plakate za IV. izložbu peradi, kunića, golubova, ptica - II. izložba pasa (1930.), proljetni ZZ - VIII. salon automobila (1931.), VII. izložbu peradi, kunića, golubova, ptica pjevica, mačaka i kakteja (1931.), jesenski XVIII. ZZ (1932.), Zimsku izložbu (1932.).

43 Godine 1936. je za ZZ trebao oblikovati spomen-listove za izlagače, ali se nacrt nije sviđao Ignjatu Fischeru. - HR-DAZG-251-10, ZSEO, 6. 11. 1936. 44 Parola »Riba je najbolje jelo - daje snagu krijepi tijelo« i dopadljivi čovječuljak koji jede ribu upućivali su na temeljnu zadaću sajma koji je nastojao popularizirati i proširiti potrošnju ribe.

45 Riječ je o dječjim pjesmicama Bolesna lutka, Lutka bez glave i druge šale za naše male, Mala majka i Roda.

46 Nekoliko njegovih djela proteklih je godina prodano putem inozemnih aukcijskih kuća, a izvori dostupni na Internetu pokazuju da su njegove slike varirale od optimističnih, narativnih, realističkih prizora razigranih mladića (npr. pred panoramom Dubrovnika ili na moru) do fantastičnih, nadrealnih ilustracija.

47 Zbor je poziv za oblikovanje plakata za jubilarni jesenski 30. ZZ uputio i Pavelu Fromanu, Sergiju Glumcu, Emilu Vičiću, Atelieru Tri i Ottu Antoniniju. - HR-DAZG-251, 112. Korespondencija, Dopis ZZ, 11. 7. 1938.

48 Primjerak plakata datiranog oko 1935. čuva se u Österreichisches Museum für angewandte Kunst u Beču (inv. br. PI 4896).

49 HR-DAZG-251, 8. Zapisnici sjednica Ekzekutivnog odbora (1931.1938.), 6. 4. 1933.

50 Arhiv ALU, Matični list br. 221. Malvine Egersdorfer. - Rođena je u Rijeci 7. listopada 1912. , završila je četiri razreda Realne gimnazije u Zagrebu (1927.), tečaj Trgovačke škole Klare Hercog u Zagrebu te Samostan Sacré coeur, Monastère de la Visitation. Zbog slabog napretka i nedolaska na nastavu na sjednici 19. prosinca 1932. onemogućen joj je upis u ljetni semestar 1932./33.

51 JANEZ DAMJAN, ŽARKO LAZAREVIČ, Vzpon in zaton največje usnjarne, Manager, 5 (2011.). Članak dostupan na: http://www.finance. si/314961/Vzpon-in-zaton-največje-usnjarne (1. 6. 2014.).

52 Šegrtsku školu na Kaptolu pohađao je 1925./26. - IVAN HRKOVAC, DRAGUTIN MATIJAŠEVIĆ, Popis učenika od 1886. do 1994. godine, u: 100 godina Grafičke škole u Zagrebu, (ur.) Želimir Grabarić, Grafička škola u Zagrebu, Zagreb, 1994.

53 HR-DAZG-251-10, ZSEO, 28. 6. 1935.

54 Godine 1929. izlazi časopis Reklama koji izdaje zavod Imago, a od sredine 1930-ih u Jutarnjem listu počela je izlaziti rubrika Reklama je moć...! 55 Bogdan Rajakovac, Savremeni jugoslavenski crtači, Novosti, XXIV/154 (5. lipnja 1930.), 9. - Rajakovac svoj opsežan tekst posvećuje suvremenom jugoslavenskom crtežu i kao posebnu dionicu ističe autore plakata uz opasku da je oblikovanje upečatljivoga "umjetničkog plakata" koji privlači zanimanje javnosti težak zadatak.

* Ovaj je rad sufinancirala Hrvatska zaklada za znanost projektom br. 4153 Croatia and Central Europe: Art and Politics in the Late Modern Period (1780-1945). 
Summary

Lovorka Magaš Bilandžić

Posters of the Zagreb Fair in the Interwar Period (1922-1940) - a Contribution to the History of Croatian Graphic Design

The Zagreb Fair (Zagrebački zbor) had a prominent role in the history of visual communications in the Kingdom of Serbs, Croats and Slovenes / Yugoslavia in the period between the two World Wars, both on practical and theoretical level. Between 1922 and 1940 the Fair commissioned over sixty posters for its spring and autumn fairs and accompanying exhibitions, which varied from traditional, illustrative and narrative to those based on patterns characteristic of commercial events throughout Europe, or posters designed by artists who reinterpreted avant-garde language, aesthetics of Art Deco or Classicist paradigm. The process of poster commission changed over the years, and the Fair gave significant attention to visual presentation of events both in the country and abroad, assigning the decisions related to various segments of its marketing activity to the Executive Board. Posters for the Fair were designed by distinguished graphic designers of the period (S. Glumac, O. Antonini, E. Vičic, members of the Atelier Tri and others), but also students of the Royal Academy of Arts and Crafts and today forgotten graphic artists such as Kornel Becic, Marcel Fišer, Malvine Egersdorfer and Zvonimir Lenard. Becić was the author of attractive and effective designs comparable to popular iconography and Disney aesthetics, Fišer introduced features of other media (film and photography) to graphic design, while Egersdorfer and Lenard embodied Art Deco fascination with speed and movement in their respective ways.

On the basis of archival records and press reports the article discusses the role of the Zagreb Fair in the promotion of graphic design and advertising, introduces a typology of the Fair's posters and interprets the contribution of artistic personalities heretofore unidentified in the history of Croatian graphic design, increasing the corpus of known posters by unpublished designs analysed as emblematic examples of visual culture of the period. 
